\title{
LAW PROTECTION FOR DOMESTIC INDUSTRIES DUE TO DUMPING PRACTICE
}

\author{
Anita Kamilah \\ Law Faculty Suryakancana University \\ E-mail: anita.kamilah@yahoo.co.id
}

\begin{abstract}
International trade is business transactions conducted across borders, which has the goal accumulated maximum profit (profit optimal). In this implementation, corporations often do business by unfair competition, such as dumping, which could damage the order of the importing country trading system. The problem is what factors are causing a corporation carrying out the practice of dumping, and also; and How is legal protection against a country as a result of dumping practices. Factors that cause dumping, to profit by setting lower prices in the import market and the monopoly in the market of the importing country. A form of protection for countries that suffered losses as a result of dumping practices which could impose "anti-dumping duty", as a punishment for the exporting country. Due to losses caused by dumping, the government should make a law that specifically regulates the protection of domestic industry due to the practice of dumping.
\end{abstract}

Keywords: Domestic industry, dumping, law protection

\begin{abstract}
Abstrak
Perdagangan internasional merupakan transaksi bisnis yang dilakukan secara lintas batas, yang memiliki tujuan akumulasi keuntungan sebesar-besarnya (optimum profit). Pelaksanaannya guna mendapatkan keuntungan tersebut korporasi sering melakukan bisnis secara unfair competition, seperti praktik dumping yang dapat merusak tatanan sistem perdagangan negara pengimpor. Permasalahannya adalah (1) Faktor-faktor apa yang menyebabkan suatu korporasi melaksanakan praktik dumping, serta (2) Bagaimanakah perlindungan hukum terhadap suatu negara akibat praktik dumping. Faktor penyebab dumping, untuk mendapatkan keuntungan dengan menetapkan harga yang lebih rendah di pasar impor dan monopoli di pasar negara pengimpor. Wujud perlindungan bagi negara yang menderita kerugian akibat praktik dumping yaitu dapat mengenakan "Bea Masuk Anti dumping", sebagai sanksi bagi negara pengekspor. Mengingat kerugian akibat dumping, sebaiknya pemerintah membuat undang-undang yang secara khusus mengatur mengenai perlindungan industri dalam negeri akibat praktik dumping tersebut.
\end{abstract}

Kata Kunci: industri dalam negeri, dumping, perlindungan hukum.

\section{Introduction}

Economic system nowadays that globalized and very integrated with science and technology supports, rise the improvement of economic world actors dependency which borderless. ${ }^{1}$ The negative effect of economical globalization is liberisation of international trade system, international capital hegemony in domes- tic area as well as the quality of the fraudulent business activity conducted by corporation in different countries, especially in Indonesia. ${ }^{2}$

The development of world economy that being more complex has led to intense competition in the international trade. Practice for winning the competition are often used by the business from various countries include using the un-

Janes Delors, "The Future of Free Trade in Europe and the World", Fordham International Law Journal, Vol. 18, Isuue 3, 1994, page. 723; Christhophorus Barutu, "Sejarah Sistem Perdagangan Internasional (Dari Upaya Pembentukan Internasional Trade Organization, Eksis-tensi General Agreement On Tariffs and Trade Sampai Berdiri-

nya World Trade Organization), Jurnal Hukum Gloris Juris, Vol. 7, No. 1. Januari 2007 Edition, Jakarta: Fakultas Hukum Universitas Katholik Atmajaya, page. 5.

2 Damianus J. Hali, "Humanisme dan Peradaban Global", Jurnal Hukum Pro Justitia, Vol. 26, No. 2, April 2008, Bandung: FH. Unpar, page 111-127. 
fair practices, one of them is through dumping. ${ }^{3}$ Dumping is the terminology that used in international trade as trade practice that done by the exporters by selling the commodity in international market at a price lower than the price it normally charges, this practice can disturb the market and parasites the producent competitors in the importing country. ${ }^{4}$ Dumping as one of corporation crime is part of "white collar crime" which by Edwin $\mathrm{H}$. Shutelannd is defined as a criminal law violation committed by people with high economic status (upper socio economic class) such as entrepreneurs and executives that detriment public interest. ${ }^{5}$

Dumping practice resulted a country that can dominates overseas market, so that give substantial constribution toward economic development in exporting countries. The importing countries is very disadvantaged by this practice as it will brings the complex economical implication and also parasites other country economy, due to compete and unsaleable in domestic market, thus leading to bankruptcy. Further consequence due to the bankruptcy of the company is the termination of the working relationship which resulted in a large number of unemployed. Remembering the big impact of dumping for a country, the question to be studied in the writing of this paper are: first, what factors lead a corporation carrying out the practice of dumping; and secondly, how does the legal protection of a country due to dumping practices?

\section{Discussion.}

\section{Factors that Affect Corporation on Doing Dum- ping Practice}

Business is one of the main activities that support economic development. The term of "business" means an activity of buying and selling commodities, products, or services. In wider definition, the term business often defined as a whole activity carried on by the person or entity that is engaged in business as a manufacturer, merchant, consumers in an industry where the company is located, carried out regularly and continuously, in the form of activities held the goods or services or facilities at which are to be sold. ${ }^{6}$

Description of the business activity is an activity that is routinely performed, in order to benefit and perform by the economic actors, both of which is not incorporated such as a trading company, firm, limited partnership (Commanditaire Vennootschap/CV) and which has the status of legal entities, such as cooperatives, foundations and limited liability companies or known by the corporation. ${ }^{7}$ The term corporation etymologically cames from latin "corporatio", which dervided from Dutch corporatie, English corporation, and corporation (Germany). Corporatio means the result of work make an agency, in other words, agencies that serve persons, entities acquired by human actions as opposed to the human body, which occurs in nature. ${ }^{8}$

According to Hans Kelsen statement, stated that:

"Corporation is: a group of individual treated by the law as unity, namely as a person having rights and duties distinct from those of the individuals composing it. A corporation is regarded as a person because there the legal orders stipulates certain legal rights and duties which concern the interests members of the corporation but which do not seem to be rights and duties of the members and are, therefore, interpreted as right and duties of the corporation itself. Such rights and duties are, in

3 Christhophorus Barutu, "Antidumping dalam General Agreement on Tariff and Trade (GATT) dan Pengaruhnya Terhadap Peraturan Antidumping Indonesia", Jurnal Mimbar Hukum, Vol. 19, No. 1. February 2007, Yogyakarta: Law Faculty of Gadjah Mada University, page 53.

4 Ni Made Ayu Krisna Cahyadi and Made Sukarsa, "Faktorfaktor yang Mempengaruhi Ekspor Kertas dan Barang Berbahan Kertas Di Indonesia Tahun 1988-2012", E-Journal Ekonomi Pembangunan, Vol. 4, No. 1, January 2014, Bali: Udayana University, page 66.

5 Supriyatna, "Ruang Lingkup Kejahatan Ekonomi”, Jurnal Ekonomi dan Kewirausahaan, Vol. 7, No. 1. April 2007, Pontianak: Tangjungpura University, page 43.

6 Dewi Astuti, "Kajian Bisnis Franchise Makanan di Indonesia”, Jurnal Manajemen \& Kewirausahaan, Vol 7 No. 1, March 2005, Surabaya: Kristen Petra University, page 84.

7 Frans H. Winarta, "Ketentuan dan Peraturan Hukum Kegiatan Bisnis", Jurnal Hukum Pro Justitia, Vol. 26, No. 1, January 2008, Bandung: Katolik Parahyangan University, page 7-11.

8 Yudi Krismen, "Pertanggungjawaban Pidana Korporasi dalam Kejahatan Ekonomi”, Jurnal Ilmu Hukum, Vol. 4, No. 1, September-January 2014, Pekanbaru: Riau University, page 140 . 
particular, created by act of the organs of the corporation". 9

Between 1883-1980 period, multinational corporations achieve a global integration process for eliminating, merger and acquisition of domestic corporations. The raise of the corporation's role, beside having a positive impact, also give a negative impact in the form of increased business crime committed by a corporation whose spectrum danger is multidimentional, that is not only harm the company's competitors, but it also has economic implications that complex and detrimental to the economy and the life of a country one of which is dumping.

Dumping is a form of international price discrimination committed by a corporation or price exporter, selling goods at lower price in overseas market than in the domestic market in order to gain an advantage over the export product. ${ }^{10}$ One example of dumping cases that quite detrimental Indonesian government and now is handle by Indonesian Antidumping Committee (KADI) is "Dumping Case Flour Import" Turkish origin, whose in 2010 as the country's largest supplier of flour by volume of $58.6 \%$ (fifty-eight point six percent). Due to dumping, based on the calculation of the Indonesian Employers Association (APINDO), the government suffered potential losses to the state reached 150 (one hundred fifty) billion. In addition, the impact on the bankruptcy of Small and Medium Enterprises (SMEs) as the largest absorber commodity flour, and finally lead to unemployment, according Bapenas, Indonesia is the country with the highest unemployment rate in Asean.

Based on exporter's purpose, market power and structure of import market, according to Robert Willig, there are 5 (five) type of dumping, those are: first, market expansion dumping, which the exporter company can gain profit by setting lower prices in the import market due to facing elasticity demand that greater as long as

Hans Kelsen, 1961, General Theory of Law and State, New York: Russel \& Russel, page 96.

10 Muhajir La Djanudin, "Mekanisme Penyelesaian Sengketa Dumping Antar Negara", ejournal Lex Administratum", Vol. 1, No. 2, April-June 2013, Sulawesi Utara: Sam Ratulangi University, page 126. the offered price is lower; second, cyclical dumping, motivation of this kind of dumping arises from the marginal cost that extremely low or vague, the possibility of production costs that accompany the condition of excess production capacity that is separate from the manufacture of related products; third, state trading dumping, the motivation can be similar with others categories of dumping, however the dominant is acquisition; fourth; strategic dumping, it is the term adopted to describe export that adverses rival company in importing country through the overall strategies of the exporting countries, either by cutting export prices and the restrictions on the entry of the same product to the market of the exporting country. If portion of the domestic market is large enough for each independent exporter in benchmarks economies of scale, then it will gain profit from the costs that incurred by foreign competitors; fifth, Predatory Dumping, is a term used to export at low prices, which have purpose to exclude competitors from the market, in order to acquire monopoly power in the market of the importing country. ${ }^{11}$

The other type of dumping in international trade practice is Sproradic dumping, it is dumping done by selling goods abroad at a short period of time at a price lower than the price in the exporting country, with the aim of abolishing the unwanted goods. Persistent dumping, namely the sale of goods in foreign markets at below domestic prices are done continuously as a continuation of the sale of goods made before. The sale is carried out by producers of goods that have a market monopoly in the country with the intent to maximize total profits by selling price of goods higher than in the domestic market. ${ }^{12}$

Based on the definition and the types of dumping, the factors that influenced corporation on doing dumping, are: first, Motif gain maximum profit, which was developed by Adam Smith as the first economist in the world (1723-1790). In order to obtain these advantages, Hans Kung

11 Muhammad Sood, 2011, Hukum Perdagangan Internasional, Jakarta: PT. Raja Grafindo Persada, page 121-122.

12 Sobri, 1986, Ekonomi Internasional, Teori, Masalah, dan Kebijaksanaannya, Yogyakarta: BPFE UII, page 91. 
(1977) argues that the classical eco-nomists and neoliberal do not give placement of ethics in the context of the national economy, because business is business, and the business that mixed with moral will lose and knocked out by itself. ${ }^{13} \mathrm{Se}$ cond, Monopoly product on the market of the importing country. This factor was inspired by the argument of Adam Smith in his book which was made in 1776 with the title: "Inquiry Into The Nature And Causes of The Wealth of Nations". Through this book as a business activity, economic actors including the Corporation left free in pursuit their economic interests, so that the free market was created that gave birth to the concept of laissez faire economy i.e. an individualistic liberal thinking that the economic system would work as well as possible without interference of government power. ${ }^{14}$ Through the theory of the Invisible Hand, Adam Smith pushed the country at that time to give individual freedom in developing the capital region at both the local and transnational. Since 1900-1903 development of monopoly capitalism that does small acquisition large capitalist by capitalist in a country, even cross country. Monopoly is the mastery of production and/or marketing of goods and/or for the use of cer-tain services by one trade or one group of businessmen. Monopoly resulted in unhealthy competition or unfair trade practice that is competition between businessmen in the exercise of the activities of manufacturing and or marketing of goods and or services done by dishonest, against the law, hampers competetion effort, as well as harming the public interest. ${ }^{15}$

\section{Law Protection for Country due to Dumping Practice}

Dumping is a trade practice that has an unfair significant effect on international trade,

13 AM. M. Hafidz and Sam'ani Sya'roni, “Etika Bisnis Al-Ghazali dan Adam Smith Dalam Perspektif Ilmu Bisnis dan Ekonomi”, Jurnal Penelitian, Vol. 9, No. 1, May 2012, Pekalongan: STAIN page 19.

14 Amin Pujiati, "Menuju Pemikiran Ekonomi Ideal: Tinjauan Filosofis dan Empiris", Jurnal Fokus Ekonomi, Vol. 10. No. 2, August 2011, Semarang: STIE Pena, page 115 and page 118.

15 Ni Wayan Ella Apryani and Ayu Putu Laksmi Danyathi, "Dumping dan Anti Dumping sebagai Bentuk Practice dalam Perdagangan Internasional”, Jurnal Kertha Nega- because of that Article VI General Agreement on Tariff and Trade (GATT) 1947 regulates antidumping. In order to prevent the dumping practice, then on June 30 1967, 25 (twenty five) GATT participant include United State had signed "Antidumping code". Then in order to implement the interpretation of Article VI, on 12 April 1979, the Tokyo Round Antidumping Code agreed in 1979 by 22 (twenty two) countries, which became effective from 1st of January 1980. This Code contains general procedures or procedures way through the implementation of Article VI of the GATT Agreement on implementation of Article VI of GATT.

The approval of the results of the Uru-guay Round negotiations in 1994, replaced by the 1979 Antidumping Code 1994 Anti-dumping Code, entitled Agreement on Implementation of Article IV of the 1994 Anti-dumping Code 1994 is actually one of the Multilateral Trade Agreement signed together with the Agreement Establishing the World Trade Organization (WTO) which is an institution that aims to promote world trade among member countries of the WTO. Antidumping notch 1994 is no longer an additional agreement as well as the GATT Anti-dumping Code 1979, but is an integral part of the Agreement Establishing the WTO itself.

Indonesia is one of the 81 country which on January 1, 1995 officially became the Original Members of WTO. ${ }^{16}$ The acceptance of the results of the Uruguay round by Indonesia looks from the enactment of Law No. 7 Year 1994 on the Ratification of the Agreement on Establishing WTO, therefore it has a valid agreement become part of national legislation and Indonesia adjusting its laws and regulations, including agreements on antidumping. ${ }^{17}$

ra, Vol. 02, No. 03, May 2014, Bali: Law Faculty of Udayana University, page 1.

16 M.E. Retno Kadarukmi, "Dampak Implementasi GATT/ WTO Terhadap Ekspor Impor Indonesia", Jurnal Administrasi Bisnis, Vol/ 9, No/ 1, 2013, Bandung: Fisip UNPAR, page 79.

17 Sutiarnoto MS., "Tantangan dan Peluang Investasi Asing", Jurnal Hukum, Vol 6, No. 3. Edisi Agustus 2001, page 271; Erman Rajagukguk, "Globalisasi Hukum dan Kemajuan Teknologi: Implikasi Bagi Pendidikan Hukum dan Pembangunan Hukum Indonesia, Jurnal Hukum, Vol. 01, No. 1, 2005, Medan: Sumatra Utara Universi-ty, page. 12. 
Law No. 17 Year 2006 on Customs, which is further elaborated in Government Regulation No. 34 Year 2011 on Antidumping Measures, Actions Rewards and Trade Security Measures in particular of Article 2 through Article 30, commissioned the Indonesian Antidumping Committee (KADI) to conduct investigation with the support of early evidence as well as a complete document about the existence of: dumping of goods; losses; and a causal link between dumping goods and Losses suffered by the applicant.

KADI can use as "While Act" if during the investigation found sufficient preliminary evidence regarding with the existence of dumping goods. Exporters and/or exporters of manufacturers directly or with the government of the exporting country, the applicant or the domestic industry and importers received notification of KADI about the use of "While Act". KADI deliver interim reports which is results of the investigation and recommend to the Minister to impose while act. Measures Adjustments Export prices or discontinuation of goods export Dumping done KADI later than 7 (seven) calendar days from the imposition date of "Import Imposition Duty While Antidumping", and in the case of "Adjustment Act" are not carried out in accordance with the memorandum of agreement, the committee is continuing the process of the import imposition duty of Anti dumping.

The regulation of antidumping in several countries exclude Indonesia: first, Australia. Before signed WTO agreement, since early 19 century, regulation of antidumping in Australia are: (a) Custums Act 1901 Part XVB; (b) Customs Tariff (Antidumping) 1975; and (c) Antidumping Authority Act 1988 . With the signing of the GATT which became the WTO juridical consequences to hold the harmonization of national laws with international regulations, such as WTO. Australia through two regulations, namely Customs Legislation (WTO Amendments Bill) and the Custom Tariff (Antidumping/World Trade Organization Amendments Bill), since January 1, 1995 set the antidumping institutions. Through both of these re- gulations, then Australia set institutes antidumping, namely: Chief Executive Officer of Customs (CEOC), assisted by the Australian Customs Service of the Department of Industry, Science and Technology Australia, which has the task of receiving petitions antidumping, determine whether an investigation can be made on the petition, and made the discovery while (preliminary finding) and Anti-dumping Authority, which is in charge of continuing the investigation results Chief Executive Officer of Customs (CEOC). Investigation files, if indicated the existence of dumping practices, it is submitted to the Authority to be re-examined Antidumping which would then be submitted to the Minister for Small Business Custom and Construction. In the final stage, Minister Antidumping Authority provide recommendations on the form of action to be taken. ${ }^{18}$

Second, United State. Since 1930 United State have been had regulations of antidumping to protect the domestic market from overseas market penetration. Antidumping regulation in United State contained in Titel VII Tariff Act 1930 then modify in Titel 19 United States Code (US Code) Section 1673 until 1677 K. The Regulation is the successor of the previous rules in 1921 and this code is valid until the US government imposed an Antidumping Code 1979. Other regulations relating to anti-dumping, namely Antidumping Act 1916 that allows a civil claim for damages against the party who did the dumping, while the rules on anti-dumping appeal against the decision stipulated in Title 28 US Code.

The competent institution is under the jurisdiction handling antidumping Department of Commerce (Commerce) and United States International Trade Commission (ITC). The determination or payment of anti-dumping duties under the authority of US Custom Service on instructions from Department of Commerce. ${ }^{19}$ Anti-dumping provisions in Indonesia, Australia and the United States, basically have the same concept that is to provide protection to the domestic industry from the disservice dumping practice.

19 Setiadi A, 2001, Antidumping dalam Perspektif Hukum Indonesia, Jakarta: S \& R Legal Consultant, page 6-9.
18 Ade Maman Suherman, 2002, Aspek Hukum Dalam Ekonomi Global, Jakarta: Ghalia Indonesia, page 145-146. 


\section{Closing}

Conclution

Based on explanation above, it can be conclude matters as follows: first, Factors that cause the corporation on implementing dumping practice that is because they want to achieve a profit by setting lower prices in the import market, if exercised in violation of business ethics. Moreover, to exclude competitors from the market in order to acquire monopoly power in the market of the importing country. Second, The Legal Protection for A Country From Dumping Practice. Countries that suffered losses due to the dumping, through the agency or committee authorized to handle the issue of dumping can impose rules on Antidumping, and can perform a civil claim for damages against the party who did the dumping.

\section{Suggestion.}

Dumping practice could harm the domestic industries in Importing Country. Therefore the government should make a reglation that specifically regulates the protection of domestic industry due to dumping. The Government should give strict punishment to the corporation convicted of dumping practices by procedure for granting customs and excise exemption.

\section{References}

A, Setiadi. 2001. Antidumping dalam Perspektif Hukum Indonesia. Jakarta: S \& $\mathrm{R}$ Legal Consultant;

Apryani, Ni Wayan Ella and Ayu Putu Laksmi Danyathi. "Dumping dan Anti Dumping sebagai Bentuk Practice dalam Perdagangan Internasional". Jurnal Kertha Negara. Vol. 02. No. 03. May 2014. Bali: Law Faculty of Udayana University;

Astuti, Dewi. "Kajian Bisnis Franchise Makanan di Indonesia". Jurnal Manajemen dan Kewirausahaan. Vol. 7. No. 1, March 2005. Surabaya: Kristen Petra University;

Barutu, Christhophorus. "Antidumping dalam General Agreement on Tariff and Trade (GATT) dan Pengaruhnya Terhadap Peraturan Antidumping Indonesia". Jurnal Mimbar Hukum. Vol. 19. No. 1. February 2007. Yogyakarta: Law Faculty of Gadjah Mada University;
" "Sejarah Sistem Perdagangan Internasional (Dari Upaya Pembentukan Internasional Trade Organization. Eksistensi General Agreement on Tariffs and Trade Sampai Berdirinya World Trade Organization). Jurnal Hukum Gloris Juris. Vol. 7. No. 1. Januari 2007. Jakarta: Fakultas Hukum Universitas Katholik Atmajaya;

Cahyadi, Ni Made Ayu Krisna and Made Sukarsa. "Faktor-faktor yang Mempengaruhi Ekspor Kertas dan Barang Berbahan Kertas Di Indonesia Tahun 1988-2012". E-Journal Ekonomi Pembangunan. Vol. 4. No. 1. January 2014. Bali: Udayana University;

Delors, Janes. "The Future of Free Trade in Europe and the World". Fordham International Law Journal. Vol. 18. Isuue 3. 1994;

Erman Rajagukguk. "Globalisasi Hukum dan Kemajuan Teknologi: Implikasi Bagi Pendidikan Hukum dan Pembangunan Hukum Indonesia. Jurnal Hukum. Vol. 01. No. 1. 2005. Medan: Sumatra Utara University;

Hafidz, AM. M. and Sam'ani Sya'roni. "Etika Bisnis Al-Ghazali dan Adam Smith dalam Perspektif Ilmu Bisnis dan Ekonomi”. Jurnal Penelitian. Vol. 9. No. 1. May 2012. Pekalongan: STAIN;

Hali, Damianus J. "Humanisme dan Peradaban Global”. Jurnal Hukum Pro Justitia. Vol. 26. No. 2. April 2008. Bandung: FH. Unpar;

Kadarukmi, M.E. Retno. "Dampak Implementasi GATT/WTO Terhadap Ekspor Impor Indonesia”. Jurnal Administrasi Bisnis. Vol. 9. No. 1. 2013. Bandung: Fisip UNPAR;

Kelsen, Hans. 1961. General Theory of Law and State. New York: Russel \& Russel;

Krismen, Yudi. "Pertanggungjawaban Pidana Korporasi dalam Kejahatan Ekonomi". Jurnal Ilmu Hukum. Vol. 4. No. 1. SeptemberJanuary 2014. Pekanbaru: Riau University;

La Djanudin, Muhajir. "Mekanisme Penyelesaian Sengketa Dumping Antar Negara". E-journal Lex Administratum". Vol. 1. No. 2. April-June 2013. Sulawesi Utara: Sam Ratulangi University;

MS, Sutiarnoto. "Tantangan dan Peluang Investasi Asing". Jurnal Hukum. Vol. 6. No. 3, Agustus 2001;

Muhammad Sood. 2011. Hukum Perdagangan Internasional. Jakarta: PT. Raja Grafindo Persada;

Pujiati, Amin. "Menuju Pemikiran Ekonomi Ideal: Tinjauan Filosofis dan Empiris”. Jurnal Fo- 
kus Ekonomi. Vol. 10. No. 2. August 2011. Semarang: STIE Pena;

Sobri. 1986. Ekonomi Internasional. Teori. Masalah. dan Kebijaksanaannya. Yogyakarta: BPFE UII;

Suherman, Ade Maman . 2002. Aspek Hukum dalam Ekonomi Global. Jakarta: Ghalia Indonesia;
Supriyatna. "Ruang Lingkup Kejahatan Ekonomi". Jurnal Ekonomi dan Kewirausahaan. Vol. 7. No. 1. April 2007. Pontianak: Tanjungpura University;

Winarta, Frans H. "Ketentuan dan Peraturan Hukum Kegiatan Bisnis". Jurnal Hukum Pro Justitia. Vol. 26. No. 1. January 2008. Bandung: Katolik Parahyangan University. 